Peer-Reviewed Article

ISSN: 2162-3104 Print/ ISSN: 2166-3750 Online

Volume 5, Issue 4 (2015), pp. 405-419

(c) Journal of International Students

http://jistudents.org/

\title{
Taboo or Tabula Rasa: Cross-Racial/Cultural Dating Preferences amongst Chinese, Japanese, and Korean International Students in an American University
}

Zachary S. Ritter, PhD

University of Redlands (USA)

\begin{abstract}
International students bring racial attitudes and group preferences that affect campus climates. Forty-seven Chinese, Japanese, and Korean college international students were interviewed, regarding their perceptions of race/ethnicity and nationality, when it comes to dating and romantic relationships on college campuses. Thirty-five out of forty-seven students interviewed said they would ideally want to date someone from their own cultural background, so that communication gaps would not occur, but when probed beyond language barriers, international students appeared to have a racial hierarchy when it came to dating. Students were not only influenced by parental approval of dating partners, but also US media images that helped create a racial hierarchy of dating and cultural capital. White Americans were the most desirable dating partner for Chinese, Japanese, and Korean international students; Asian-Americans were slightly below white Americans, while African-American, Latino, and Southeast Asian students were the least desirous.
\end{abstract}

Keywords: Interracial dating, Asian international students, Cross-cultural interactions, Racial attitudes, Stereotype reduction

Chinese, Japanese, and Korean international students bring with them racial stereotypes that affect who they choose to befriend and date (Ritter, 2013). These racial stereotypes often stem from a complex history of race relations, as illustrated by football player Hines Ward's life. "I'm a half-Korean. I will do my best for the Korean community. My (Korean) mother's blood flows in my body" (Ahn, 2013). Hines Ward, a mixed heritage African-American and Korean National Football League (NFL) player addressed a Korean audience, as he visited Korea, for the first time. His visit triggered a discussion of Korea's troubled history of mixed-race relations, signaling a new awareness of racial politics in Korea (Ahn, 2013). His mother was a waitress and his father was an American soldier stationed in South Korea. They moved to America when Ward was one year old, because his mother's family was ashamed of her marriage to a black 
man. When the newly desegregated American military arrived in Korea, during the Korean War (1950-1953), Korean civilians were influenced by white GI's racial attitudes of white superiority and black inferiority. The adoption of negative black stereotypes stemmed from Koreans' fear of 'regressing' back into a perceived dark-skinned third world status, in a world composed of a black, white, and Asian global hierarchy (Russell, 1991).

Korean society's embrace of Ward's blackness (only on the grounds that he embraced his mother's Koreanness more) illustrates the racial divides that still exist in transnational romantic relationships as well as the racism mixed heritage individuals often face in East Asia. Ward's bloodline was always in question because of his dark skin; therefore, he had to prove his Koreanness by demonstrating that he ate kimchi, and that he had a close bond with his mother (whom he bought a mansion for and decorated it in a Korean style). Interethnic marriages comprised eleven percent of marriages in Korea in 2007, but many of these unions were Vietnamese and Filipina brides seeking better lives with Korean men, in the Korean countryside (Le, 2011). While intermarriage in East Asian cities continues to be somewhat taboo, American rates of intermarriage are increasing, albeit slowly.

In the 2012-2013 academic year, US college enrollment of international students rose to 819,644 students (Institute of International Education, 2013). As Chinese, Japanese, and Korean international students become a larger portion of the U.S. higher education landscape (194,029, 19,966, 72,295, respectively, studied in the U.S. in 2011/2012 academic year), there must be more research looking at all aspects of how international students are changing U.S. campus racial climates (Institute of International Education, 2013). As this population grows, researchers must take a closer look at racial attitudes of these students who will be future employers and will assume positions of power in both America and their home countries. Additionally, if higher education faculty and administrators hope to promote a democratic multicultural society (Gutmann, 1999) and a culture of racial tolerance (UC Diversity Mission Statement, 2014), we must understand international students' perceptions toward interracial/interethnic romantic dating.

\section{Racial and Status Hierarchy Theory}

Racial and status hierarchies greatly affect Chinese, Japanese, and Korean international students' romantic partner choice process (Ritter, 2013). Grant and Lee (2009) explain that many Korean immigrants view the American racial landscape in the frame of Bonilla-Silva's (2004) Tri-Racial System. There are whites, honorary whites, and collective blacks in this schema, which resembles Latin or Caribbean-like racial orders. Whites occupy the highest standing and possess the largest cultural capital. Honorary whites are somewhat accepted by the white community and have gained this prestigious space in society through educational attainment, income, occupational level, and skin color. Honorary whites and collective blacks feud to gain access to the honorary white class. International students may gain access to the societal prestige, by learning English well, earning a degree from an American college, and befriending socially desirous out-group members (Grant \& Lee, 2009). East Asian international students who study in the West, oftentimes, gain cultural, economic, and social capital by doing so, thus, improving their social standing in the US and abroad.

An unfortunate by-product of Chinese, Japanese, and Korean international students' desire to improve their social status is the adoption of negative stereotypes that the American dominant social groups tend to perpetuate through media and other outlets. The collective black 
group (which includes some Latinos, Southeast Asians, and other marginalized groups) is relegated to the bottom totem of the racial hierarchy, which is observed and internalized by international students. To compound this problem, Chinese, Japanese, and Korean international students often lack a deep understanding of racial apartheid, slavery, historical and modern institutional racism, which has led to the economic disenfranchisement of many AfricanAmericans. Instead, some international students think that personal incompetence and misfortune have led to black incarceration and poverty (Grant \& Lee, 2009). International students, when studying in the U.S, tend to distance themselves from collective blacks, in order to gain acceptance into the honorary white category (Bonilla-Silva, 2004), which can have deleterious effects for college campus climates and cross-cultural/racial understanding, as illustrated below in the literature review.

\section{Literature Review}

\section{Interracial/International Dating and Marriage in China, Japan, and Korea}

As China's economy has become more globalized, mixed marriages have increased (Murphy, 2013), thus possibly influencing the racial attitudes Chinese international students bring with them to the U.S. A large number of Chinese youth have experienced conservative attitudes toward romantic relationships, but since 1990 (the opening of the modern Chinese economy), Western dating influences have resulted in a normalization of heterosexual relations at a younger age (Zheng, Zhou, Zhou, Liu, Li \& Hesketh, 2011). One ethnographic study found that Shanghai women perceive relationships with western men as an opportunity for romantic and sexual experimentation outside of traditional Chinese gender roles and expectations, as well as a way to possibly garner transnational cultural capital (Carmel, 2004). In the 1980s Chinese women who dated foreign men could lose their jobs, be kicked out of university, or banished to the countryside (Farrer, 2010). But by 2000, many university administrators in Shanghai began turning a blind eye to the sexual behaviors of college students (Farrer, 2006). In 2012, there were 53,000 registered marriages in China, between Chinese and foreign nationals, indicating a drastic change from 1978, when there were zero (Murphy, 2013). White westerners (more commonly men) appear to be more desired by Chinese nationals, over poorer African immigrants, because they are viewed as having higher levels of education, do not have the racial stigma associated with blackness (Yeebo, 2013), and are believed to have greater wealth (Murphy, 2013).

In Korea, in 2005, marriages to foreigners accounted for 14 percent of all marriages in South Korea, up from 4 percent in 2000 (Onishi, 2007). A booming industry which finds Vietnamese and Filipino brides for rural Korean men have led to about 19,000 Vietnamese women immigrating as brides (Le, 2011). However, cross-cultural misunderstandings, feelings of ethnic superiority on the part of some Koreans, and mentally ill husbands have led to multiple cases of Southeast Asian brides being murdered by their spouses (Le, 2011); forcing Korean officials to look more seriously at issues of diversity and assimilation (Le, 2011). As illustrated in the study below, we find that a majority of Korean international students did view Southeast Asians and Africans/African-Americans as less desirous to date, which is closely tied with attitudes toward these two groups in Korea.

Japanese students, in the current study, proved to be the most liberal in their attitudes toward mixed marriages, which may be explained by the economic and cultural closeness Japan has had with the U.S. since World War II. In Japan, the number of interracial marriages is 
increasing more slowly compared to Korea, with 5 percent (40,154 interethnic marriages out of $735,132)$ interracial marriages in 2006. As in rural Korea, we see predominantly Filipina $(12,150)$ and female Chinese $(12,131)$ brides coming to Japan for a better life, while only 1,474 marriages were between US men and Japanese women in 2006 (Japanese Ministry of Health, Labour and Welfare, 2006). In an effort to tackle the problem of declining birth rates and a larger population of immigrant workers, in 2010, Korea introduced a dual nationality law that grants citizenship to children born out of international unions. And in 2008, Japan passed a law allowing citizenship to a child born to a Japanese father and a foreign mother (Chung \& Kim, 2012). While China, Japan, and Korea, have histories of racial superiority, racial purity myths, and xenophobia (Dikotter, 1997; Kim, 2008), modern trends of declining birth rates (in Japan), and a globalizing world, may be resulting in more liberal attitudes toward international and interracial marriages.

\section{Romantic Dating Preferences Based on Race}

Students from China, Japan, and Korea are influenced by the international trends in interracial dating, but they are affected by American trends as well. Fujino (1997) and Yancey (2002) found that interracial dating among Americans was more common when both identity group members had been exposed to each other's out-group at a young age, either through schooling or common neighborhoods. Research of American youth, indicate that interracial and interethnic daters were more likely to have lower levels of prejudice toward racial out-groups and were more willing to befriend and live with racial out-groups (Mok, 1999). College students who exhibited lower levels of in-group favoritism, intergroup anxiety, and in-group identification before coming to college, were more likely to date racial out-groups during college (Levin, Taylor, \& Claude, 2007). Parental approval also played a role in inter-racial dating, in so far as Asian-Americans, Latinos, and white American college students were more likely to date within their own ethnic group when they perceived that their parents, as well as the parents of their romantic partner, would approve of inter-group dating (Edmonds \& Killen, 2009; Field, Kimuna, \& Straus, 2013; Liu, Campbell, \& Condie, 1995).

In Liu, Campbell, and Condie’s study (1995), Asian-American and Latino students rated opposite-sex whites as more attractive than members of their own in-group. Furthermore, Latinos and African-Americans rated whites and Asian-Americans as having a higher status, which was mostly defined as education and income. The perceived attractiveness and high status of AsianAmerican and white students illustrated that these two groups were perceived to be highest on a social and racial hierarchy (Feliciano, Robnett, \& Komaie, 2009).

\section{Research Method}

Forty-seven semi-structured interviews (60-90 minutes in length) were conducted with twentythree Chinese students, thirteen Japanese students, eight Korean students, two Hong Kong students, and one Taiwanese student. Each student who was interviewed was given a pseudonym to protect his/her identity. Data was analyzed through a constant comparative method (Glaser, 1965), whereby each coded theme was compared to the prior coded theme. In time, themes reached a point of saturation where additional ones did not add new insight to the analysis (Jones, Torres, \& Armino, 2006). The researcher conducted three stages of coding: open coding, axial coding, and selective coding (Strauss \& Corbin, 1998).

September/October $2015 \quad$ http://jistudents.org $\quad$ Volume $5 \bullet$ Issue 4


Table 1

Student Participants by Age, Gender, College Level, Time in the US and College Major

\begin{tabular}{|c|c|c|c|c|c|c|c|}
\hline Name & Aqe & Gender & Home & Colleae Level & Time in & Major & Livina \\
\hline $\operatorname{Rex}$ & 20 & $\mathrm{M}$ & China & Undergraduate & 3-4 vears & Engineering & On \\
\hline Zhun & 23 & $\mathrm{~F}$ & China & Undergraduate & $1-3$ & Engineering & Off \\
\hline Rui & 19 & $\mathrm{~F}$ & China & Undergraduate & $1-2$ & Undeclared & On \\
\hline Guo & 24 & M & China & Undergraduate & 3-4 years & Architecture & Off \\
\hline Sherly & 21 & $\mathrm{~F}$ & China & Undergraduate & $1-3$ & English & Off \\
\hline Bao & 23 & M & China & Undergraduate & 3-4 years & Math/Econ & Off \\
\hline Han & 25 & $\mathrm{M}$ & China & Undergraduate & $1-3$ & Science/Enginee & Off \\
\hline Dae & 21 & $\mathrm{~F}$ & Korea & Undergraduate & $1-3$ & Political science & Off \\
\hline Linzy & 23 & $\mathrm{~F}$ & Korea & Undergraduate & 3-4 years & Psychology & Off \\
\hline Jay & 34 & M & Korea & Graduate & $1-2$ years & Public policy & Off \\
\hline Himal & 45 & $\mathrm{~F}$ & Korea & Graduate & $1-2$ years & Elec. Engineer & Off \\
\hline Keiko & 23 & $\mathrm{~F}$ & Japan & Undergraduate & $4-6$ & Political Science & On \\
\hline Hideki & 23 & M & Japan & Undergraduate & $1-3$ & Comm. Studies & On \\
\hline Shiso & 35 & $\mathrm{~F}$ & Japan & Graduate & $4-6$ & Computer & Off \\
\hline Han & 26 & M & China & Graduate & 3-4 years & Science/Enginee & Off \\
\hline Mei & 40 & $\mathrm{~F}$ & China & Graduate & $7-11$ & Education & Off \\
\hline Gong & 27 & M & China & Graduate & $1-3$ & Engineer & Off \\
\hline Sean & 23 & M & China & Graduate & $1-2$ years & Engineer & Off \\
\hline Winnie & 25 & $\mathrm{~F}$ & China & Graduate & $4-6$ & Finance & Off \\
\hline Chin & 25 & $\mathrm{M}$ & China & Graduate & $4-6$ & Business & Off \\
\hline Amy & 24 & $\mathrm{~F}$ & China & Graduate & $4-6$ & Education & On \\
\hline Hank & 22 & M & China & Undergraduate & $5+$ years & Economics & Off \\
\hline Zeek & 20 & M & China & Undergraduate & $1-3$ & Sociology & On \\
\hline Collin & 20 & M & China & Undergraduate & $1-3$ & Physiological & On \\
\hline Yenzi & 30 & $\mathrm{~F}$ & China & Graduate & $4-6$ & Biostatistics & Off \\
\hline Ally & 19 & $\mathrm{~F}$ & China & Undergraduate & $4-6$ & Psychobiology & On \\
\hline Lan & 29 & $\mathrm{~F}$ & China & Graduate & 3-4 years & Engineer & Off \\
\hline Behao & 19 & M & China & Undergraduate & $1-3$ & Economics & On \\
\hline Mingqu & 18 & $\mathrm{~F}$ & China & Undergraduate & $4-6$ & Economics & On \\
\hline Elena & 21 & $\mathrm{~F}$ & China, & Undergraduate & $5+$ years & English & Off \\
\hline Erin & 29 & $\mathrm{~F}$ & China, & Graduate & $1-2$ years & Cinema & Off \\
\hline Min & 32 & M & Taiwan & Graduate & $5+$ years & Management & Off \\
\hline Cattie & 23 & $\mathrm{~F}$ & China & Graduate & $4-6$ & Engineer & Off \\
\hline June & 21 & $\mathrm{~F}$ & Korea & Undergraduate & 3-4 years & Math/econ & On \\
\hline Ja-Sun & 20 & $\mathrm{~F}$ & Korea & Undergraduate & $5+$ years & Psychology & On \\
\hline Young & 31 & $\mathrm{~F}$ & Korea & Graduate & $1-2$ years & Education & Off \\
\hline Yoon & 28 & $\mathrm{~F}$ & Korea & Graduate & $5+$ years & Education & Off \\
\hline Riu & 24 & M & Japan & Undergraduate & $1-3$ & Economics & Off \\
\hline Momok & 26 & $\mathrm{~F}$ & Japan & Undergraduate & $5+$ years & Asian studies & Off \\
\hline Taka- & 24 & $\mathrm{M}$ & Japan & Undergraduate & 3-4 years & Political Science & On \\
\hline Yuki & 22 & $\mathrm{~F}$ & Japan & Undergraduate & $1-3$ & Economics & Off \\
\hline Saiko & 30 & $\mathrm{~F}$ & Japan & Graduate & $1-3$ & Education & Off \\
\hline Emiko & 22 & $\mathrm{~F}$ & Japan & Undergraduate & $1-3$ & Law & Off \\
\hline Kosu & 22 & $\mathrm{M}$ & Japan & Undergraduate & 3-4 years & Political Science & Off \\
\hline Kenny & 22 & $\mathrm{M}$ & Japan & Undergraduate & $1-3$ & Engineer & On \\
\hline Cat & 26 & $\mathrm{~F}$ & Japan & Graduate & $1-3$ & Education & On \\
\hline Roko & 25 & $\mathrm{~F}$ & Japan & Graduate & $5+$ years & Anthropology & On \\
\hline
\end{tabular}


The study was conducted at University of California at Los Angeles (UCLA), due to the ethnic and international diversity of the campus. It was part of a larger study that looked at racial stereotypes of East Asian international students in general, but the topic of interracial dating came to be quite significant. In the 2011/2012 academic year, UCLA was ranked sixth in the nation, when it came to international student populations, with 2,761 Chinese students, 1112 Korean students, and 322 Japanese students. Undergraduate and graduate international students made up six percent of the total UCLA population (40,675) (UCLA Open Doors Report, 2013). Graduate and undergraduate students were interviewed in order to get a variety of responses. The research question is as follows: How do racial/ethnic stereotypes of Chinese, Japanese, and Korean international students influence their perceptions of interracial/interethnic dating?

Students were recruited from the Dashew UCLA International Center, through a combination of purposeful and snowball sampling to participate in the semi-structured interviews (Babbie, 2007). The International Center has various American culture workshops, an international-domestic big buddy program, and language circles where international students teach their native language to domestic students.

All interviews were audio recorded and transcribed verbatim by the researcher using Microsoft Word and a hand held tape recorder. Interviews were all conducted in English by a Caucasian interviewer, which may have affected interviewee responses, however, similar responses were found in other studies that had Caucasian and Asian-American interviewers (Kim, 2008; Talbot, Geelhoed, \& Ninggal, 1999). Memo-writing was conducted during and after interviews in order to capture thoughts, analytical leads, and assumptions (Charmaz, 2001).

In order to add a level of trustworthiness and validity to the study, the researcher utilized the technique of member checking. This involves reiterating information given by respondents in order to make sure the researcher understands his/her participants' thoughts, feelings, and ideas (Lincoln \& Guba, 1986). Students were able to request the transcripts of their interview at any point and change their responses, if desired.

\section{Findings}

\section{Asian International Students’ Attitudes Toward Dating White-Americans}

The predominant view toward dating was that marrying within one's own ethnicity was the most practical and comfortable (as also reported in Levin, Taylor, \& Claude, 2007). But when considering dating outside one's race/ethnicity, a majority interviewed, were interested in dating white people (similar to the findings in Feliciano, Robnett, \& Komaie, 2009; Tsunokai, McGrath, \& Kavanagh, 2013). Behao, a Chinese undergraduate economics major living in the U.S. for three months, explained that if a Chinese woman has a white husband, in China, that was considered "honorable." Behao said it was closely linked to perceived status based on skin color and a Western archetype of beauty: "The first impression thing, when we see a white person we see well-educated, rich, and tall." This snap judgment approach of associating whiteness with positive traits was expressed by thirty percent interviewed. The desire to want to date a white person was often based on global racial and economic hierarchy (Brown, 2000; Kim, 2011; Grant \& Lee, 2003; Marginson, 2008; Marginson \& Sawir, 2005).

All three students who dated white students, were comfortable with English, were well adjusted to life in America, had attended several years of high school in America, and planned to live in the US long-term. A Chinese graduate student, Han, was well acculturated to life in 
America and also had a white girlfriend. He was a material science graduate student, living in the U.S. for three years. He explained that he was attracted to white women, not because they represented a position of high status in society, but because he liked their physical appearance and their open communication style. Asian women's faces were too flat and round, in his opinion, but white women's faces were "three-dimensional." He clarified that all races and ethnicities could be attractive, but that he preferred white women. This was partly due to the media's glamorization of white women, but it also had to do with ways of communicating within relationships: "White girls are more open. When there is something wrong they will tell you, but Chinese girls will hide their feelings."

Han was representative of students who had been in America three years or more, who felt that they were becoming global citizens or more Asian-American. Thus, it was not exactly the act of being in a relationship with a white-American that made these students more openminded and improved their English, rather they already had these traits prior to entering the relationship. Interestingly enough, these three students explained that they did not deliberately seek out white-American partners, but they said unconsciously that societal influences of beauty and status played into their romantic choice.

\section{Asian International Students’'Attitudes Toward Dating African-Americans}

This racial/status hierarchy and negative attitude toward dating African-Americans also affected Chinese international students' views. Zhun, a Chinese graduate engineer living in the U.S. for three months explained what she perceived to be a dominant Chinese racial hierarchy:

I think in [Chinese] people's minds there is a ranking where there are black boys, white boys, and Asian boys. Well, Chinese people think that Africa is comparatively poor and America is richer so it is better to have a white boyfriend. And Chinese people think that white is the most beautiful. Like if you are white there is a saying... that [being] white can cover up all your ugliness. So we think white is a beautiful color for girls. Boys like girls whose skin is white...So we buy products that make us more white.

Zhun's explanation conflated African-American and African men. In her view, black skin was synonymous with poverty, whereas whiteness was associated with western industrialized nations and wealth. Zhun's words reflected Bonilla-Silva's (2004) racial hierarchy as well as a fear of slipping back into a Chinese third world status, which was connoted by blackness (Russell, 1991). Dating a black person was thought to lead someone to become part of the collective black group, and possibly lessen their social and cultural capital. Chinese students seemed to be more tolerant than Korean students, when it came to dating racial out-groups, but there was still a prevailing unease when it came to dating African-Americans amongst all Asian international students.

Himal, a Korean post-doc visiting scholar in the sciences, represents Korean international students who did not attend international schools and was not exposed to racial/cultural diversity growing up. She did not have much contact with African-American people and was heavily influenced by the film The Gods Must Be Crazy. This comedic film depicted African men as uneducated hunters from the rural areas of Africa. A majority of international students were influenced by media portrayals of Africans and African-Americans as being criminals, uneducated, athletes, or rap artists, which often led to social distancing. She commented that she 
would not date or marry a black person not only because of her stereotypes, but because of the discrimination her child would face if he/she were half-black:

I would worry for my daughter's future if she had dark skin. Korea would not accept her. If I think about [the] second generation, it does matter. If it was just me with some guy, it doesn't matter, but thinking about the next generation, I wouldn’t marry.

Himal felt that raising a family with a black person meant that her child would be discriminated against in Korea, possibly like NFL player Hines Ward's mother experienced. For Himal, skin color was closely linked with wealth, status, and class; therefore, having a black child would hinder her child's chances of success in Korea. When asked if she would marry a Japanese or Chinese person, Himal explained that she would be open to it because historical animosities and Japanese colonization was a thing of the past. She explained that "nowadays, maybe Korea will become wealthier than Japan. Why should I hate Japanese people?" This response illustrated that economic status of countries was almost more important than ethnicity. Himal, and three other Korean students, spent a significant amount of time comparing different country's gross domestic products (GDP) and explaining that Korea was surpassing other countries because of Korean people's hard working culture and parental emphasis on education (Apple, 2000; Kim, 2011). Himal was forty-five-years-old and represented the three older international students in the study, who were less open to diversity, grew up in a less globalized Korea (Vandrick, 2011). Nonetheless, younger Korean students seemed to harbor the most negative views toward Latinos and African-Americans out of the three nationality groups interviewed.

\section{Attitudes Toward Dating Latinos}

Many international students interviewed knew very little about Latino people, but quickly learned from observations in everyday life and American media. Linzy, who had lived in the U.S. for 4 years, indicated that she was not interested in dating Latino men because they had a different lifestyle and culture than her own. When pressed as to what this really meant, she said she had seen white boys who had Korean girlfriends and they were really sweet and affectionate to them. But she never saw Latino men date her Korean friends (this behavior was not normalized in her mind), thus it was something that was taboo and unknown. She said she had negative stereotypes toward Latinos because whenever she went to restaurants, they were "the people washing dishes and doing all the dirty work, right? So I guess that is like how the country discriminates against them. Because most of them are illegal immigrants, right?” Here, it appears that dating outside of the Asian-white paradigm may be a status lowering activity (Apple, 2000; Kim, 2011).

Another Korean undergraduate student who had been in America for 3 months, Dae, said she was influenced by a film that portrayed Mexicans as illegal immigrants as well as her cousin's words of caution that Mexican people were likely to break into her car and steal her belongings. These racial stereotypes were combined with a lack of understanding about American race relations and historical disparities between racial groups, as evidenced by a Korean humanities graduate student's words. Jay, a Korean political science graduate student explained that: “...they don’t pay attention to education. Japanese, Chinese, and Korean society 
has frenzy for higher education. But I was told that the Latino people are not so interested in pursuing higher education or studying hard."

Jay compares the culture of East Asians as one of hard work ethic and educational attainment, which stands in stark contrast to his perceived cultural values of Latinos. International students knew little about this racial out-group, but quickly started putting information they gleaned from everyday life to understand this new racial landscape in the US. Students who had taken diversity courses (four graduate students) and had prolonged engagement with Latino classmates explained that they felt a connection with Latino students. They felt that both Latinos and Asian internationals had strong Christian morals, family values, and a strong work ethic. On the whole, Latinos occupied a liminal space on international students' racial hierarchies below Asians, but above African-Americans as dating partners.

\section{Asian Internationals’ Attitudes Toward Dating Asians and Asian-Americans}

A majority of students indicated that they would be comfortable dating Asian-American students of their own ethnic background (Levin, Taylor, \& Claude, 2007), but felt that AsianAmerican students did not want to date them because of the cultural divide between international and domestic students. Additionally, when it came to inter-Asian international dating, historical conflicts and parental messages were potent factors in the decision making process (Edmonds \& Killen, 2009; Field, Kimuna, \& Straus, 2013; Liu, Campbell, \& Condie, 1995). Stereotypes of a given Asian international ethnic group were often conflated with an Asian-American ethnic group.

Amy, a Chinese humanities graduate student from Nanjing, explained that her parents would not be pleased if she dated a Japanese national or a Japanese-American person because members of her family were killed during the massacre of Nanjing during World War II. As Peng (2010) indicated, many Chinese citizens believed that Japanese were cruel, cunning, and mean, due to the massacres committed during World War II. Similarly, Takahashi, a Japanese humanities undergraduate living in America for three years, was open to dating American minority groups and white Americans, but knew that marrying a Korean-American or ChineseAmerican person would have detrimental effects for him in the future:

Because a lot of Japanese people have a negative view toward [Chinese and Korean people], if I marry them, then my social status would go down, my reputation. 'Oh he is marrying a Chinese or Korean, that is abnormal or unusual,' people might think. But Black, Latino, or white, they don't have negative views of them, so I think it is ok to marry them.

Japanese students in the study tended to be more liberal toward dating domestic students than Chinese or Korean international students. Over half of the international students interviewed saw Asian-Americans as having a white middle-class American culture, with a mix of a national ethnic culture as well. This led to erroneous transnational ethnic stereotypes, wherein Asian international students applied their learned stereotypes of Chinese, Japanese, and Koreans from their home country, to Asian-Americans. International students, who were new to the country (lived here three months or less), and/or had little contact with Asian-Americans, were more likely to link an Asian national stereotype with that of an Asian-American ethnic group. 
Even when it came to Asian-American and Asian international dating, status, wealth, and power dynamics came into play. Min, a Taiwanese humanities graduate student, living in the US for five years, explained why he felt Asian-American women were not interested in dating Asian internationals and more inclined to date American-born-Chinese men: Because they "want to pursue a higher status” partner.

Min attributed American born Chinese women's lack of interest in dating Asian international students to status differences. He considered Asian-Americans to be part of the honorary whites' group that held more social and cultural capital than Asian internationals (Bourdieu, 1986; Bonilla-Silva, 2004); therefore, he believed Chinese-American women may be more attracted to Asian-American men.

This dynamic of status also played a role in East Asian international students' perceptions of dating Southeast Asians. Ally, a 19 year-old Hong Kong science undergraduate student who had several residential life leadership roles, explained that she would not date her BurmeseAmerican co-worker because "a person from Manhattan would not date a Brooklyn person. Those uptown girls don't date Brooklyn guys.” There was a perceived economic difference, where she was the Manhattan, upper class woman, who would not dare think of dating a lowerclass Brooklyn man. But thinly veiled, beneath this analogy was a long history of racial/ethnic superiority, colonialism, and a dark-light skin dichotomy between East Asians and Southeast Asians (Dikotter, 1997; He, 2005; Johnson, 2007; Liu, 2006). She conflated ethnicity and socioeconomic status because she went on to say that Southeast Asians usually represented poverty and were involved with drugs. She said, "we want to date [someone from] a better social class. I would love to make friends with them, but when it comes to dating, it is totally another issue." Ally went through diversity training with the office of residential life and she thought of herself as very tolerant of others. She explained that many of her friends were from various racial/ethnic backgrounds; however, Ally held prejudices toward Southeast Asians that could affect how she treats others in her role as a student leader.

\section{Discussion}

Thirty-five out of forty-seven students interviewed said they would ideally want to date someone from their own cultural background so that language and communication gaps would not occur. These students exhibited more in-group favoritism, thus they were less likely to date outside their nationality group (Levin, Taylor, \& Claude, 2007). Almost all students in the study said they were accepting of other people dating interracially and that mixed heritage children, especially Caucasian and Asian children were beautiful. However, when asked if they would date someone who was African-American, Latino, or Southeast Asian, students were very hesitant to say they would date these groups because these three groups represented lower socioeconomic status groups in American and their home countries (Feliciano, Robnett, \& Komaie, 2009; Tsunokai, McGrath, \& Kavanagh, 2013). Students explained that they did not want to appear racist and that they believed that all people should be treated equally. But racial socialization processes in their home countries and parental views toward culture and race were major factors that went into the dating decision making process (Edmonds \& Killen, 2009; Field, Kimuna \& Straus, 2013).

Japanese students were more open to Latino or African-American people, compared to Korean or Chinese students. This finding may be explained by the high English proficiency levels, socially liberal attitudes, Americanization of Japanese culture (Beck, Sznaider, \& Winter,

September/October 2015 http://jistudents.org $\quad$ Volume $5 \bullet$ Issue 4


2003; Franz \& Smulyan, 2012) and the larger presence of American ex-patriots in Japan. Korean students seemed to be the least open to interracial dating, which may be explained by the historical homogeneity of Korea (Kim, 2008). Chinese students were somewhere in the middle (between Japanese and Korean students), in their openness toward interracial dating, which may be a result of the rapid economic rise of China combined with an influx of foreign investors and various ethnic groups to China (Montalvo \& Reynal-Querol, 2005).

Chinese, Japanese, and Korean international students indicated that Asian-American students were uninterested in dating Asian international students because of a perceived status difference. They considered Asian-Americans to be part of the honorary whites' group that held more social and cultural capital than Asian internationals (Bourdieu, 1986); Bonilla-Silva, 2004). It appears as though Asian international students were striving to become part of the honorary white category (Bonilla-Silva, 2004), by earning a degree in America and befriending and dating students with perceived cultural capital (Asian-American and white students).

Of the three students who did date interracially, all expressed the importance interracial dating has in stereotype reduction. Gaertner and Dovidio (2000) Recategorization Model calls for out-group and in-group members to re-imagine their social groupings and to form new ones based on common in-group identities. These three interracial couples began to see their partners in a less racialized lens, making new categories for their romantic partners that went beyond race.

\section{Limitations}

A limitation in this study was the lack of deeper analysis regarding the heterogeneity that exists within the Chinese, Japanese, and Korean populations being studied. The literature review paints a historical picture of bias and racism, but this does not mean that the ideas expressed in the interviews were held by all East Asian international students. The study illustrated that some students from China, Japan, and Korea did have racist attitudes; however, this was only a qualitative study of 47 students. The study by no means seeks to indicate that all students from these countries hold negative attitudes toward American racial minority groups. In order to be more generalizable, there must be a quantitative study, with a larger population size, that includes more Asian countries.

\section{Conclusion and Recommendations}

This research begs the question of whether these results would have been different if whiteAmerican students were asked similar questions regarding their stereotypes. Asian international students are not socialized in an American environment where the ghost of slavery and Jim Crow are taught in k-12 education, thus international students may not fully understand the troubled history of U.S. race relations and they may also not use politically correct language when discussing race. American college students may hold similar global racial hierarchies, but have been taught to speak in a politically correct manner, when talking about people with darker skin or non-white features (Norton, Sommers, Apfelbaum, Pura, \& Ariely, 2006), whereas Asian international students may filter their speech less, when discussing racial biases. One way to ameliorate this issue is not to teach international students how to adopt a politically correct lexicon, but to teach classes that discuss racial politics and civil rights movements in America, 
deconstruct Hollywood portrayals of racial groups, and teach inter-cultural communication skills.

UCLA International Center programs have been effective in exposing international students to racial diversity; however, there must be a more concerted effort to expose and educate East Asian International students about African-American and Latino heritage and history (Chang, 2002; Hurtado, Dey, Gurin, \& Gurin, 2003). The Intergroup Dialogue Program created at the University of Michigan, encourages students to challenge their racial perceptions through experiential learning, talking about privilege and oppression and conducting community action projects that bring together disparate racial communities. UCLA International Center programs such as Global Siblings, which pairs international students with domestic student mentors should be expanded. Additionally, themed on-campus housing, where international students and domestic students have programs around mutual cultural learning can be effective at stereotype reduction. It would also be beneficial to have an American history/government requirement for international students, which discusses race relations in a US context (Lin \& Yi, 1997). A stronger multicultural curriculum in the k-12 system in East Asian countries would also be beneficial.

Asian international students are coming to America with a racial hierarchy (Ritter \& Roth, 2014), which may also perpetuate racial hierarchies and affect how and with whom they date. Student affairs officers and policy makers should discuss American racial stereotypes in orientation sessions, encourage international students to take diversity courses, create programs that allow international and domestic students to positively interact, and create housing accommodations that allow for cross-racial contact and prejudice reduction to take place.

\section{REFERENCES}

Ahn, J.-H. (2013). Rearticulating Black mixed-race in the era of globalization. Cultural Studies, 4, 1-27.

Apple, M.W. (2000). Between neoliberalism and neo-conservatism. In N. C Burbules \& C. A Torres (Eds.), Globalization and education: Critical perspectives. New York, NY: Routledge.

Babbie, E. (2007). The practice of social research. Belmont, CA: Thompson Wadsworth.

Beck, U., Sznaider, N., \& Winter, R. (2003). Global America?: The cultural consequences of globalization. Liverpool, UK: Liverpool University Press.

Bonilla-Silva, E. (2004). From bi-racial to tri-racial: Towards a new system of racial stratification in the USA. Ethnic and Racial Studies, 27, 931-950.

Bourdieu, P. (1986). The forms of capitals. In Handbook of theory and research for the sociology of education, ed. J. Richardson, 241-54. Westport, CT: Greenwood Press.

Brown, P. (2000). The globalization of positional competition? Sociology, 34(4), 633-53.

Carmel, I. (2004). Foreign Romance, Modernity and Power: Cross-Cultural Relationships and the Changing Lives of Chinese Women in Shanghai (Master's Thesis). Monash University School of Languages Cultures and Linguistics.

Chang, M. J. (2002). The impact of an undergraduate diversity course requirement on students' racial views and attitudes. Journal of General Education, 51(1), 21-42.

Charmaz, K. (2001). Grounded theory. In Contemporary Field Research: Perspectives and Formulations. Prospect Heights, IL: Waveland Press.

Chung, E. A., \& Kim, D. (2012). Citizenship and marriage in a globalizing world: Multicultural 
families and mono-cultural nationality laws in Korea and Japan. Indiana Journal of Global Legal Studies, 19 (1), 195-219.

Dikotter, F. (1997). The construction of racial identities in China and Japan: Historical and contemporary perspectives. Honolulu: University of Hawaii Press.

Edmonds, C., \& Killen, M. (2009). Do adolescents’ perceptions of parental racial attitudes relate to their intergroup contact and cross-race relationships? Group Processes \& Intergroup Relations, 12, 5-21.

Farrer, J. (2006). Sexual citizenship and the politics of sexual storytelling among Chinese youth. In E. Jeffries (Ed.), Sex and Sexuality in China, pp. 102-23. London, UK: Routledge.

Farrer, J. (2010). A Foreign adventurer's paradise? Interracial sexuality and alien sexual capital in reform era Shanghai. Sexualities, 13(1), 69-95.

Feliciano, C., Robnett, B., \& Komaie, G. (2009). Gendered racial exclusion among White internet daters. Social Science Research, 38, 39-54.

Field, C. J., Kimuna, S. R., \& Straus, M. (2013). Attitudes toward interracial relationships among college students: Race, class, gender, and perceptions of parental views. Journal of Black Studies, 44, 741-776.

Franz, K., \& Smulyan, S. (2012). Major problems in American popular culture: Documents and essays. Australia: Wadsworth Cengage Learning.

Fujino, D. C. (1997). The rates, patterns, and reasons for forming heterosexual interracial dating relationships among Asian Americans. Journal of Social and Personal Relationships, 14, 809-828.

Gaertner, S. L., \& Dividio, J. F. (2000). Reducing intergroup bias: The common identity model. Hillsdale, NJ: Psychology Press.

Glaser, B. G. (1965). The constant comparative method of qualitative analysis. Social Problems, 12(4).

Grant, R. A., \& Lee, I. (2009). The Ideal English Speaker. In R. Kubota \& A. M. Y. Lin (Eds.), Race, culture, and identities in second language education: Exploring critically engaged practice. New York, NY: Routledge.

Gutmann, A. (1999). Democratic education, with a new preface and epilogue. Princeton, NJ: Princeton University Press.

He, B. (2005). Minority rights with Chinese characteristics. In W. Kymlicka \& B. He (Eds.) Multiculturalism in Asia. Oxford, UK: Oxford University Press.

Hurtado, S., Dey, E. L., Gurin, P. \& Gurin, G. (2003). College environments, diversity, and student learning. In J. C. Smart (Ed.), Higher education: Handbook of theory and research 18, (pp.145-90). UK: Kluwer Academic Publishers.

Institute of International Education: Open Doors Data. (2013). http://www.iie.org/

Research-and-Publications/Open-Doors/Data/International-Students.aspx

UCLA Open Doors Report. (2013). Institute of International Education: UCLA, Internal Document.

Japanese Ministry of Health, Labour and Welfare. (2006). Retrieved from http://www.mhlw.go.jp/english/database/db-hw/report/5.html

Johnson, D. (2007). Race and racism in the Chinas: Chinese racial attitudes toward Africans and African-Americans. Bloomington, IN: Author.

Jones, S. R., Torres, V., \& Arminio, J. L. (2006). Negotiating the complexities of qualitative research in higher education: Fundamental elements and issues. New York, NY: Routledge. 
Kim, J. (2011). Aspiration for global cultural capital in the stratified realm of global higher education: Why do Korean students go to US graduate schools?, British Journal of Sociology of Education, 32(1), 109-126.

Kim, N. (2008). Imperial citizens: Koreans and Race from Seoul to LA. California, CA: Stanford University Press.

Le, J. (2011). Till death do us part: Foreign Vietnamese bride killed in South Korea. Vietnam Talking Points: One Vietnam Network. Retrieved from http://talk.onevietnam.org/til-deathdo-us-part-foreign-vietnamese-bride-killed-in-south-korea/

Lee, J., \& Rice, C. (2007). Welcome to America? International student perceptions of discrimination. Higher Education, 53, 381-409.

Levin, S., Taylor, P., \& Caudle, E. (2007). Interethnic and interracial dating in college: A longitudinal study. Journal of Social and Personal Relationships, 24, (3), 323-341.

Lincoln, Y.S., \& Guba, E.G. (1986). But is it rigorous? Trustworthiness and authenticity in naturalistic evaluation. New Directions for Program Evaluation, 30, 73-84.

Liu, H. (2006). The Chinese overseas. London, UK: Routledge.

Liu, J. H., Campbell, S. M., \& Condie, H. (1995). Ethnocentrism in dating preferences for an American sample: the in-group bias in social context. European Journal of Social Psychology, 25(1).

Marginson, S. (2008). Global field and global imaging: Bourdieu and worldwide higher education. British Journal of Sociology of Education 29(3), 303-15.

Marginson, S., \& E. Sawir. (2005). Interrogating global flows in higher education. Globalization, Societies, and Education 3(3), 281-310.

Mok, T. A. (1999). Asian American dating: Important factors in partner choice. Cultural Diversity and Ethnic Minority Psychology, 5, 103-117.

Montalvo, J., \& Reynal-Querol, M. (2005). Ethnic diversity and economic development. Journal of Development Economics, 76(2), 293.

Murphy, Z. (2013). Mixed marriages in China a labour of love. BBC News.

Norton, M., Sommer, S. Apfelbaum, E., Pura, N., \& Ariely, D. (2006). Color blindness and interracial interaction: Playing the political correctness game. Psychological Science, 17(11), 949.

Onishi, N. (2007). Marriage brokers in Vietnam cater to S. Korean bachelors. Asia PacificInternational Herald Tribune. Retrievedfromhttp://www.nytimes.com/2007/02/21/world/ asia/21ihtbrides.4670360.html ?pagewanted=1

Peng, S.-Y. (2010). Impact of stereotypes on intercultural communication: a Chinese perspective. Asia Pacific Education Review, 11(2), 243-252.

Ritter, Z. (2013). Making and breaking stereotypes: East Asian international students' experience with cross-racial interactions (Dissertation). UCLA, Los Angeles.

Russell, J. (1991). Race and Reflexivity: The Black Other in Contemporary Japanese Mass Culture. Cultural Anthropology, 6(1), 3-25

Strauss, A., \& Corbin, J. (1998). Basics of qualitative research: Techniques and procedures for developing grounded theory. Thousand Oaks, CA: Sage.

Talbot, D., Geelhoed, R., \& Ninggal, M. T. (1999). A qualitative study of Asian international students' attitudes toward African-Americans. NASPA Journal, 36(3).

Tsunokai, G. T., McGrath, A. R., \& Kavanagh, J. K. (2013). Online dating preferences of Asian Americans. Journal of Social and Personal Relationships.

UC Diversity Mission Statement. (2014). Retrieved from http://www.gdnet.ucla.edu/

September/October $2015 \quad$ http://jistudents.org $\quad$ Volume 5•Issue 4


gasaa/admissions/diversity.htm

UCLA, Undergraduate Admissions, (2013). Quick facts about UCLA. Retrieved from http://www.admissions.ucla.edu/campusprofile.htm.

Vandrick, S. (2011). Students of the new global elite. TESOL Quarterly: Journal for Teachers of English to Speakers of Other Languages and of Standard English As a Second Dialect, 45(1), 160-169.

Yancey, G. (2002). Who interracially dates: An examination of the characteristics of those who have interracially dated. Journal of Comparative Family Studies, 33, 179-190.

Yeebo, Y. (2013). In China, mixed marriages can be a labor of love. In one major Chinese city, marriages between Chinese and Africans are on the rise. Christian Science Monitor. Retrieved from http://www.csmonitor.com/World/2013/0921/In-

China-mixed-marriages-can-be-a-labor-of-love

Zheng, W., Zhou, X., Zhou, C., Liu, W., Li, L., \& Hesketh, T. (2011). Detraditionalisation and attitudes to sex outside marriage in China. Culture, Health \& Sexuality, 13(5) 497-511.

\section{AUTHOR}

ZACHARY S. RITTER, PhD, is an Associate Director of Campus Diversity and Inclusion and an Adjunct Professor in the School of Education, University of Redlands, CA. Email: zack_ritter@redlands.edu 